\title{
Ecosystem respiration in a heterogeneous temperate peatland and its sensitivity to peat temperature and water table depth
}

\author{
Radosław Juszczak • Elyn Humphreys • \\ Manuel Acosta • Maria Michalak-Galczewska • \\ Dariusz Kayzer • Janusz Olejnik
}

Received: 28 October 2011 / Accepted: 22 August 2012 / Published online: 13 September 2012

(C) The Author(s) 2012. This article is published with open access at Springerlink.com

\begin{abstract}
Background and aims Ecosystem respiration $\left(R_{e c o}\right)$ is controlled by thermal and hydrologic regimes, but their relative importance in defining the $\mathrm{CO}_{2}$ emissions in peatlands seems to be site specific. The aim
\end{abstract}

Responsible Editor: Per Ambus.

R. Juszczak $(\bowtie) \cdot$ M. Michalak-Galczewska $\cdot$ J. Olejnik Department of Meteorology,

Poznan University of Life Sciences,

Piątkowska 94,

60649 Poznan, Poland

e-mail: radoslaw.juszczak@up.poznan.pl

E. Humphreys

Department of Geography \& Environmental Studies,

Carleton University,

B349 LA, 1125 Colonel By Dr.,

Ottawa, Ontario K1S 5B6, Canada

M. Acosta $\cdot$ J. Olejnik

Department of Matter and Energy Fluxes, Global Change Research Center, AS CR,

v.v.i. Brno, Czech Republic

D. Kayzer

Department of Mathematical and Statistical Methods,

Poznan University of Life Science,

Wojska Polskiego 28,

60637 Poznan, Poland

M. Acosta

Department of Physics, Division of Atmospheric Sciences, University of Helsinki,

FI-00014 Helsinki, Finland of the paper is to investigate the sensitivity of $R_{\text {eco }}$ to variations in temperature and water table depth (WTD) in a wet, geogenous temperate peatland with a wide variety of vegetation community groups.

Methods The $\mathrm{CO}_{2}$ fluxes were measured using chambers. Measurements were made at four microsites with different vegetation communities and peat moisture and temperature conditions every 3 to 4 weeks during the period 2008-2009, 2 years with contrasting WTD patterns. Models were used to examine the relative response of each microsite to variations in peat temperature and WTD and used to estimate annual total $R_{\text {eco }}$.

Results Temporal variations in $R_{\text {eco }}$ were strongly related to peat temperature at the $5 \mathrm{~cm}$ depth. However, two of the microsites did not show any significant change in this relationship while two others showed contrasting responses including an increase and decrease in temperature sensitivity with deeper WTD. Average $R_{\text {eco }}$ varied among the microsites and tended to be greatest for those with greatest leaf area which also positively correlated with deeper WTD, ash content and degree of peat decomposition at $20 \mathrm{~cm}$. A combined temperature and WTD model explained up to $94 \%$ of the temporal variation in daily average $R_{\text {eco }}$ and was used to show that on an annual basis, $R_{\text {eco }}$ was between 5 and $18 \%$ greater in the warmer year with deeper WTD.

Conclusion Microsite-specific responses were related to differences in vegetation and peat characteristics among microsites. $R_{\text {eco }}$ may have remained insensitive to WTD variations at one microsite due to the 
dominance of autotrophic respiration from abundant sedge biomass. At a Sphagnum-dominated microsite, a lack of response may have been due to relatively small variations in WTD that did not greatly influence microbial respiration or due to offsets between decreasing and increasing respiration rates in nearsurface and deeper peat. The microsite with the most recalcitrant peat had reduced $R_{\text {eco }}$ sensitivity to temperature under more aerobic conditions while another microsite showed the opposite response, perhaps due to less nutrient availability during the wet year. Ultimately, micro-site specific models with both soil temperature and WTD as explanatory variables described temporal variations in $R_{e c o}$ and highlighted the significant spatial variations in respiration rates that may occur within a single wetland.

Keywords Ecosystem respiration · Geogenous peatland $\cdot$ Chamber measurements $\cdot \mathrm{CO}_{2}$ fluxes · Water table depth

$\begin{array}{ll}\text { Abbreviations } \\ E_{o} & \text { Parameter for respiration model } \\ F_{C-C O 2} & \mathrm{CO}_{2} \text { flux } \\ P & \text { Peat ash content } \\ R & \text { Degree of peat decomposition } \\ R_{\text {eco }} & \text { Ecosystem respiration } \\ R_{e c o-d} & \text { Daily average ecosystem respiration } \\ R_{r e f} & \text { Reference respiration at } 10.0{ }^{\circ} \mathrm{C} \\ T_{d} & \text { Average daily temperature } \\ T_{5} & 5 \text { cm peat soil temperature } \\ \text { EC } & \text { Electrical conductivity } \\ \text { LAI } & \text { Leaf area index } \\ \text { NRMSE } & \text { Normalized root mean square error } \\ \text { RMSE } & \text { Root mean square error } \\ \text { WTD } & \text { Water table depth } \\ \text { WTD }_{d} & \text { Average daily water table depth }\end{array}$

\section{Introduction}

Peatlands cover less than $3 \%$ of the Earth's surface, but contain more than one-third of the terrestrial carbon (Gorham 1991). Carbon accumulation is mainly due to the imbalance between plant uptake of atmospheric $\mathrm{CO}_{2}$ through photosynthesis and $\mathrm{CO}_{2}$ release through plant respiration (autotrophic respiration) as well as slow decomposition of organic matter (heterotrophic respiration). The sum of autotrophic and heterotrophic respiration is defined as ecosystem respiration $\left(R_{\text {eco }}\right)$.

Water table depth (WTD) is expected to regulate decomposition rates of organic matter by establishing aerobic and anaerobic zones within the peat profile (Clymo 1983). When the water table drops, oxygen diffusion into soils is increased enabling more efficient aerobic decomposition and leads to an increase in $\mathrm{CO}_{2}$ emissions from soils (Moore and Knowles 1989; Silvola et al. 1996; Nykänen et al. 1998). This effect is clearly demonstrated in laboratory incubation experiments (e.g. Moore and Dalva 1993, 1997; Waddington et al. 2001; Blodau et al. 2004), but field measurements show considerable variability in the relationships between WTD and $\mathrm{CO}_{2}$ fluxes from peatland ecosystems. Field studies have both supported (e.g. Silvola et al. 1996; Bubier et al. 2003; Tuittila et al. 2004; Riutta et al. 2007; Sulman et al. 2009) and rejected (e.g. Updegraff et al. 2001; Lafleur et al. 2005; Dimitrov et al. 2010) the hypothesis that WTD strongly influences peatland $R_{\text {eco }}$. Most often, temperature is the dominant environmental control on temporal variations in peatland $R_{e c o}$ (e.g. Chojnicki et al. 2010; Juszczak et al. 2012; Michalak et al. 2010; Mäkiranta et al. 2009; Silvola et al. 1996; Lafleur et al. 2005). Warmer air and soil temperatures stimulate microbial activity resulting in higher $\mathrm{CO}_{2}$ emissions (e.g. Frolking and Crill 1994; Silvola et al. 1996). However, the temperature sensitivity of $R_{e c o}$ in peatlands is reported to be highly variable within and between sites (Drösler et al. 2006; Mäkiranta et al. 2009). Temperature response of heterotrophic respiration processes may depend on the chemical composition of substrates and nutrient availability (Blodau et al. 2004; Updegraff et al. 2001). Consequently, as WTD varies, the quality and quantity of the peat exposed to aerobic respiration differs and may lead to variable rates of decomposition and responses to temperature (e.g. Updegraff et al. 1995; 1998). For example, excessive surface dryness in upper peat layers and anoxic conditions in deeper peat layers may simultaneously limit the volume of easily decomposable organic matter and reduce the number of microbial decomposers, which may restrict respiration processes (Mäkiranta et al. 2009). Lafleur et al. (2005) suggested that autotrophic respiration may be more closely related to temperature variations and relatively insensitive to WTD variations. This may be most notable for peatlands with abundant vascular vegetation that can increase their rooting depth with lowering water table (Murphy and Moore 2010). However, for non- 
vascular species such as Sphagnum, capitula become desiccated as the distance to the water table increases beyond a certain site- and species-specific threshold and/or there is a lack of incoming precipitation (Robroek et al. 2009). Consequently, reductions in autotrophic respiration could be expected with lower water table. Using a process-based model, Dimitrov et al. (2010) showed that the insensitivity of $R_{\text {eco }}$ to declining WTD at one bog peatland may be due to an offset between decreasing microbial respiration in the nearsurface desiccation zone and increasing root and microbial respiration in aerated peat below the desiccation zone. They further suggested that with the declining WTD, an increase in aerobic respiration in hollows was offset by reduced autotrophic respiration by drying moss on hummocks.

In this paper we investigate the relationships between $R_{\text {eco }}$ and peat temperature and WTD over a two-year period with contrasting WTD patterns to determine the importance of these factors in controlling $R_{\text {eco }}$ in a relatively wet, heterogeneous, geogenous peatland. Using chamber flux measurements of $R_{\text {eco }}$ within four different vegetation communities within a single peatland and thus experiencing the same weather conditions, we examine the temperature response of $R_{\text {eco }}$ and how it changes between the two study years in order to assess the importance of vegetation and peat characteristics on WTD controls on $R_{\text {eco }}$. Finally, we show that a multiple linear regression model with both peat temperature and WTD can describe variations in daily $R_{\text {eco }}$ and be used to estimate annual $R_{\text {eco }}$.

\section{Materials and methods}

Study site

The Rzecin peatland (POLWET) is a large ( $87 \mathrm{ha}$ ) mesotrophic, geogenous, terrestrialisation peatland (according to Joosten and Clarke 2002), located in the middle of the Notecka Primeval Forest in Western Poland $\left(52^{\circ} 45^{\prime} \mathrm{N}\right.$ latitude, $16^{\circ} 18^{\prime} \mathrm{E}$ longitude, 54 ma.s.1.) (Fig. 1). Small farms are located on the edge of the peatland close to the forest, but the anthropogenic pressure exerted on the ecosystem is rather small. In the middle of the peatland, there is a $70-\mathrm{cm}$ thick floating carpet of peat-substrate overgrown mostly by mosses underlain by saturated sediment. The distance between the peatland surface and the mineral bedrock increases from $2 \mathrm{~m}$ in the periphery to $11 \mathrm{~m}$ towards the center of the peatland. In the eastern part of the peatland there is a shallow $\sim 16$ ha decaying lake which has been overgrown mostly by Typha latifolia L. and Phragmites australis (Cav.) Trin. ex Steud. The vegetation of the peatland is dominated by the following plant species: Sphagnum spp., Dicranum spp., Carex spp., P. australis, T. latifolia, Oxycoccus palustris Pers., Drosera rotundifolia L., Potentilla palustris L., Ranunculus acris L. and Menyanthes trifoliata L. (Wojterska 2001). The soil is a Limnic Hemic Floatic Ombric Rheic Histosol (Epidystric) according to FAO 2006 classification. Annual average air temperature and total precipitation at the site are $8.5^{\circ} \mathrm{C}$ and $526 \mathrm{~mm}$, respectively.

\section{Flux measurements}

Four different microsite types with three replicates each for a total of 12 plots were established in 2007 for chamber flux measurements. Microsite S1 was dominated by the sedge Carex elata All. covering $13 \%$ of the peatland area, S2 by the reed Calamagrostis stricta (L.) Roth and the herb Menyanthes trifoliata L. (7 \%), S3 by Carex spp., Oxycoccus palustris Pers. and with a nearly continuous cover of Sphagnum teres (Schmp.) Ångstr. (6\%) and S4 by M. trifoliata, O. palustris, a small amount of the sedge Carex rostrata Stokes and a nearly continuous cover of Sphagnum fallax (Klinggr.) Klinggr. (4\%). There are 33 plant communities described for the Rzecin wetland (Wojterska 2001) with the four mentioned above covering $30 \%$ of the total peatland area.

The microsite plots are located close to a $400 \mathrm{~m}$ long wooden board walk in the north-south direction. At the end of this path there is a tower with an eddy covariance system and weather station. The microsites are characterized in detail in Table 2. Chamber flux measurements were made on permanent collars made from PVC $(75 \mathrm{~cm} \times 75 \mathrm{~cm})$ installed in 2007 . The insertion depth of the collar was about $20 \mathrm{~cm}$. Collars were not fixed such that they moved along with the seasonal movement of the floating moss carpet. Elevated boardwalks were constructed to allow access to the plots without disturbing the plant cover and peat during measurements.

A chamber system (a non-steady-state flow-through chamber system according to Livingston and Hutchinson 1995) was used to measure $\mathrm{CO}_{2}$ fluxes. 
Fig. 1 Location of the Rzecin wetland and chamber measurement sites

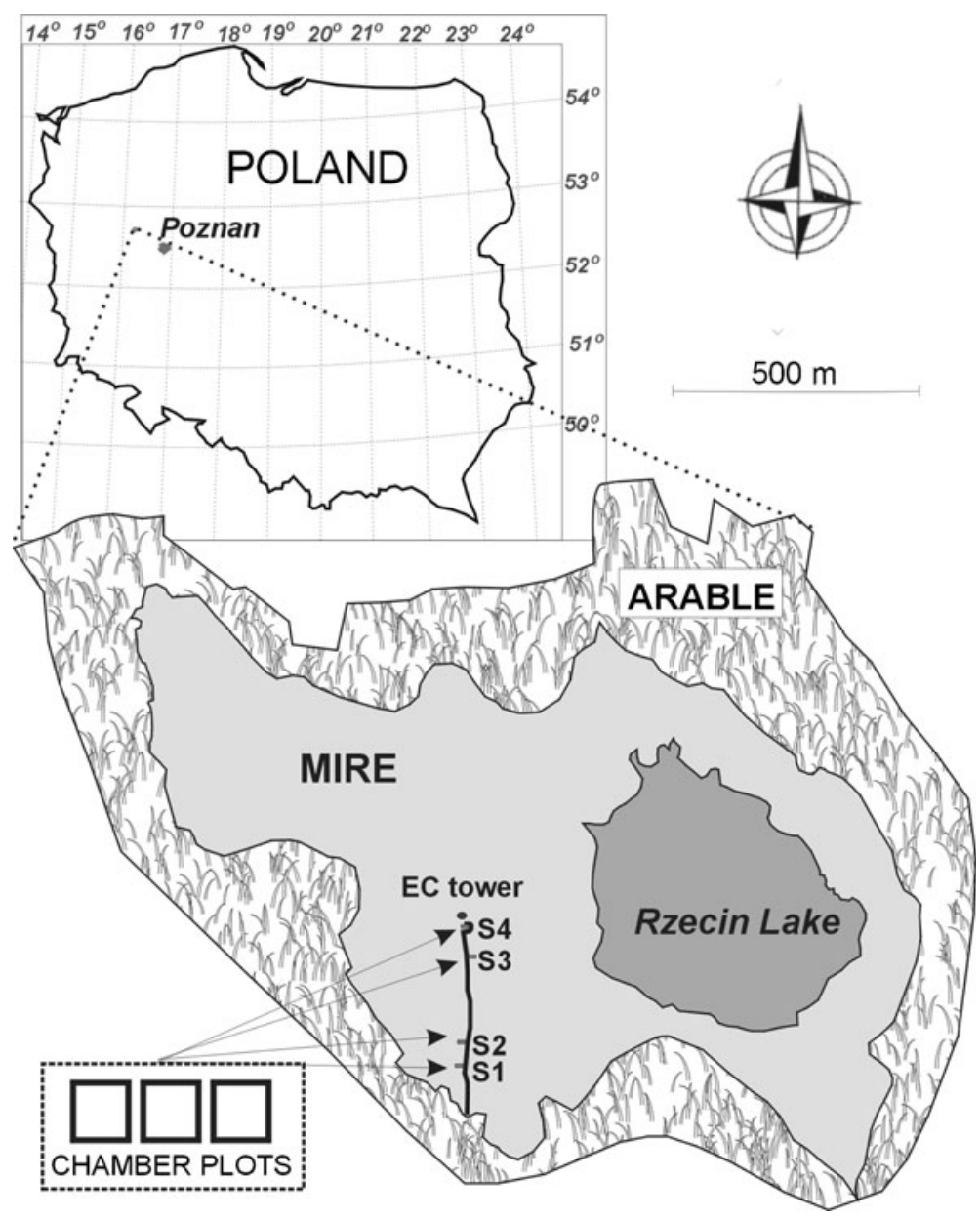

The chamber $(77 \mathrm{~cm} \times 77 \mathrm{~cm} \times 50 \mathrm{~cm})$ was made from $3 \mathrm{~mm}$ thick white (non-transparent) PVC to ensure dark conditions and a total volume of $0.3 \mathrm{~m}^{3}$. The chamber was equipped with two small fans $(1.2 \mathrm{~W})$ to effectively mix the air in the chamber headspace during measurements (Christiansen et al. 2011). Two radiationshielded thermistors (T-107, Campbell Scientific, USA) were installed to measure air temperature inside and outside the chamber. Additionally, peat temperatures were measured within each collar at 2, 5 and $10 \mathrm{~cm}$ depth (T-109, Campbell Sci., USA). Pressure changes during chamber placement were minimized by a $6 \mathrm{~mm}$ diameter and $40 \mathrm{~cm}$ long vent tube. Before a measurement, the chamber was well ventilated (fans were switched on and the chamber was manually shaken) to be sure that the starting $\mathrm{CO}_{2}$ concentration in the chamber headspace was close to the ambient concentration. During measurements, the chamber was fixed onto the collars by two elastic belts connecting the top of the chamber and the base of the frame. A rubber gasket at the base of the chamber helped ensure an airtight seal. Air was circulated at approximately $6 \mathrm{Lmin}^{-1}$ between the chamber and a portable control box containing an infrared gas analyzer (LI-820, Licor, USA), which measured $\mathrm{CO}_{2}$ concentration in the air connected to a bypass flowing at $0.6 \mathrm{Lmin}^{-1}$. During a single flux measurement, the chamber remained in place between $150 \mathrm{~s}$ in summer to $240 \mathrm{~s}$ in winter. The concentration and air and peat temperature readings were recorded at 5-s intervals on a data logger (CR-1000, Campbell Sci., USA) installed in a portable control box. All measured variables and the system performance were checked during measurements. In order to identify each of the measurement plots, the chamber was equipped with a bar code scanner (the bar code label on the metal stick was preinstalled at each plot before measurements). Finally, WTD was measured manually during flux measurements using a $5 \mathrm{~cm}$ diameter PVC well located just outside of the collars. The reference level for WTD was the peat surface in each of the collars. Note that 
WTD measurements during chamber measurements at each plot began June 2008. Estimates of WTD during chamber measurements at each microsite for January through May 2008 were estimated using regression relationships with continuous measurements at the weather station as described below.

$\mathrm{CO}_{2}$ fluxes were calculated from the change in $\mathrm{CO}_{2}$ concentration in the chamber headspace over time as determined by linear regression. The determination coefficient $\left(r^{2}\right)$ was calculated for each time series and if $r^{2}>0.8$, then $\mathrm{CO}_{2}$ flux rate $\left(F_{C-\mathrm{CO} 2}\right)$ was calculated and used for modeling. To ensure that good quality near-zero fluxes were not erroneously excluded by this criteria, all rejected fluxes were visually inspected. Fluxes of $\mathrm{CO}_{2}$ were calculated from

$$
F_{C-\mathrm{CO}_{2}}=\frac{P \cdot V \cdot \delta v}{R \cdot T \cdot t \cdot A}
$$

where $\mathrm{F}_{\mathrm{C}-\mathrm{CO} 2}$ is the $\mathrm{CO}_{2}$ flux $\left[\mu \mathrm{mol} \cdot \mathrm{CO}_{2}-\mathrm{C} \cdot \mathrm{m}^{-2} \cdot \mathrm{s}^{-1}\right.$, $\mathrm{P}$ is the atmospheric pressure $[\mathrm{Pa}], \delta \mathrm{v}$ represents $\mathrm{CO}_{2}$ concentration change in the chamber headspace $\left[\mu \mathrm{mol} \mathrm{mol}{ }^{-1}\right], \mathrm{V}$ is the total volume of the chamber headspace and the collar $\left[\mathrm{m}^{3}\right], \mathrm{R}$ is the gas constant $\left[\mathrm{Pa} \cdot \mathrm{mol}^{-1} \cdot \mathrm{K}^{-1}\right], \mathrm{T}$ is the air temperature in the chamber $[\mathrm{K}], \mathrm{t}$ is the chamber closure time $[\mathrm{s}]$ and $\mathrm{A}$ is the chamber area $\left[\mathrm{m}^{2}\right]$.

Fluxes were measured during the daytime over a 2 day period every 3 to 4 weeks beginning June 2007 . Following the methodology described by Drösler (2005), chamber measurements were conducted only under cloudless conditions and both transparent and opaque chambers were used to measure net ecosystem exchange (NEE) and $R_{e c o}$, respectively. The data collected with the opaque chamber in 2008-2009 are reported in this paper such that $R_{e c o}=F_{C-C O 2}$. Flux measurements were started just before sunrise and were conducted until the late afternoon when the peat temperatures started to decrease. For logistical reasons, only two microsites were measured during 1 day. The number of $R_{\text {eco }}$ measurements carried out on each microsite in the course of 1 day varied depending on the day length and were between 12 in winter and 30 in summer period. In total, there were $1265 R_{\text {eco }}$ measurements in 2008 and 725 measurements in 2009 (over a total of 46 site visits).

LAI was measured every $2-4$ weeks with a plant canopy analyzer (model LAI-2000, LI-COR, Inc,
Lincoln NE, USA). The values were corrected to represent only green leaf area. Moss leaf area was not included in the data presented here. $\mathrm{pH}$ and electrical conductivity were measured in the wells during the chamber measurements using a $\mathrm{pH} /$ conductometer (CPC-411, Elmetron, Poland). Peat samples from $20 \mathrm{~cm}$ depth were collected in March 2012 and analyzed for ash content using a muffle furnace set to $550{ }^{\circ} \mathrm{C}$ for $3 \mathrm{~h}$ (PN-G-04596 1997) and degree of peat decomposition using microscope analysis (PN-G04595 1997).

In addition to the microsite-specific variables, air temperature at the height of $2 \mathrm{~m}$, peat temperature at 2 , $4,6,10,20,30$ and $50 \mathrm{~cm}$ and WTD were continuously measured at the weather station on the eddy covariance flux tower in the middle of the peatland, 20 to $250 \mathrm{~m}$ from the chamber sites (Fig. 1).

\section{Modeling of ecosystem respiration $\left(\boldsymbol{R}_{e c o}\right)$}

Temperature dependent model of $\mathrm{R}_{\text {eco }}$

Temporal variations in peat temperature at $5 \mathrm{~cm}$ depth explained much of the variability observed in $R_{\text {eco }}$ at the Rzecin peatland (Juszczak et al. 2012). Consequently, this temperature was used for modeling $R_{\text {eco }}$ in this study. Continuous $30 \mathrm{~min}$ records of soil temperature at 4 and $6 \mathrm{~cm}$ at the weather station were averaged and used to develop continuous records of $5 \mathrm{~cm}$ peat temperature for each microsite using linear regressions between the weather station record and the $5 \mathrm{~cm}$ peat temperature measured during chamber measurements. The coefficient of determination and RMSE for these relationships varied from 0.75 to 0.78 and 1.46 to 1.63 , respectively ( $n=198$ to 227 ).

The respiration model of Lloyd and Taylor (1994) was parameterized using the data recorded during the 2008 and 2009 measurement periods for each microsite. This model depicts increasing temperature sensitivity with decreasing temperature. For each data set, the model-specific regression coefficients, $R_{r e f}$ and $E_{o}$ were defined by using the graph fitting software of SYSTAT (Table Curve 2D). The Lloyd and Taylor (1994) exponential function used for modeling of $R_{\text {eco }}$ fluxes is as follows:

$R_{e c o}=R_{r e f} \cdot e^{E_{0}\left[1 /\left(T_{\text {ref }}-T_{0}\right)-\left(1 /\left(T_{\text {peat }}-T_{0}\right)\right)\right]}$ 
where $R_{\text {eco }}$ is the ecosystem respiration $\left[\mu \mathrm{mol} \cdot \mathrm{CO}_{2}\right.$ $\left.\mathrm{C} \cdot \mathrm{m}^{-2} \cdot \mathrm{s}^{-1}\right], T_{\text {peat }}$ is the peat temperature $[\mathrm{K}]$ at the $5 \mathrm{~cm}$ depth measured at the time of $\mathrm{CO}_{2}$ fluxes measurements, $R_{r e f}$ is the peat respiration $\left[\mu \mathrm{mol} \cdot \mathrm{CO}_{2}\right.$ $\left.\mathrm{C} \cdot \mathrm{m}^{-2} \cdot \mathrm{s}^{-1}\right]$ at the reference temperature $T_{\text {ref }}$ of $283.15 \mathrm{~K}\left(10.0{ }^{\circ} \mathrm{C}\right)$. The parameter $E_{0}[\mathrm{~K}]$ characterizes the temperature sensitivity of respiration processes. Parameter $T_{0}$ is the minimum temperature at which respiration reaches zero $\left(227.13 \mathrm{~K}\left(-45.6{ }^{\circ} \mathrm{C}\right)\right.$ ) (Lloyd and Taylor 1994). The coefficient of determination and RMSE for these relationships varied from 0.80 to 0.88 and 0.86 to 1.59 , respectively ( $n=335$ to 398 ).

Temperature and water table depth dependent model of $R_{\text {eco }}$

The $R_{\text {eco }}$ was modeled for each microsite as a relationship between measured average daily $R_{\text {eco }}(n=12$ to $30)$, average daily $\mathrm{WTD}\left(\mathrm{WTD}_{d}\right)$ and average daily $5 \mathrm{~cm}$ peat temperature $\left(T_{d}\right)$. Again, the model was parameterized separately for the four microsites but in this case, the data from the 2 years was combined. The site specific $\mathrm{WTD}_{d}$ was modeled based on the linear regressions between WTD measured directly at the microsite during the time of chamber campaigns and the daily average WTD measured at the weather station. The coefficient of determination and RMSE for these relationships varied from 0.45 to 0.68 and 0.16 to 0.23 , respectively ( $n=65$ to 72 ).

A simple multiple linear regression was used to investigate this relationship:

$R_{\text {eco-d }}=b_{0}+b_{1} \cdot T_{d}+b_{2} \cdot W T D_{d}+b_{3} \cdot T_{d} \cdot W T D_{d}$

where $R_{\text {eco-d }}$ is the daily average $\mathrm{CO}_{2}$ emissions $\left[\mathrm{g} \mathrm{CO}_{2}-\mathrm{C} \cdot \mathrm{m}^{-2} \cdot\right.$ day $\left.^{-1}\right]$, and $b_{0}, b_{1}, b_{2}, b_{3}$ are the regression coefficients. $\mathrm{WTD}_{d}$ is expressed in $[\mathrm{cm}]$, while $T_{d}$ in $\left[{ }^{\circ} \mathrm{C}\right]$.

Due to the specific performance of this model, some simulated daily $R_{\text {eco }}$ were found to have negative values, especially when the water table was close to or just above the surface and peat temperature was very low. To exclude this artifact $\left(R_{\text {eco }}\right.$ cannot have negative values), the negative values were substituted by " 0 ".

Models were developed based on the regressions between a randomly selected subset of $70 \%$ of measured data from 2008 to 2009 and environmental drivers (peat temperature and WTD). In the next step, the remaining $30 \%$ of measured data was then used to test the developed $R_{\text {eco }}$ models. In addition to coefficients of variation, goodness-of-fit parameters normalized root mean square error (NRMSE) and root mean square error (RMSE) were calculated to assess the model success. The NRMSE is expressed in percent and is calculated as the RMSE divided by the range of $R_{\text {eco }}$ values for each microsite for the whole measurement period. Practically, the lower the NRMSE the better is the conformity between observed and simulated values.

\section{Results}

Weather and vegetation characteristics

On average, both annual and summer (June 1 - August 31) air temperature was about $1.0^{\circ} \mathrm{C}$ warmer in 2008 than in 2009. There was similar annual and summer precipitation during the 2 years however in 2008 , WTD was nearly $22 \mathrm{~cm}$ deeper (microsite S1) in summer (Table 1 and Fig. 2). This arose due to a prolonged dry period from early May to mid July 2008.

Microsites differed from each other in a variety of ways (Table 2). The two microsites with nearly continuous Sphagnum cover (S3 and S4) had lower vascular plant LAI but a lower degree of peat decomposition at $20 \mathrm{~cm}$ depth possibly due to the recalcitrant nature of Sphagnum or the slightly wetter conditions at these sites. In contrast, the sedge-dominated S1 microsite had greatest LAI and the driest conditions in summer (Fig. 2b). This may have been due to relatively greater evapotranspiration rates of the dense canopy of sedges and/or due to closer proximity to the edge of the wetland where there may have been less movement of the surface. The plots near the centre of the floating peatland (i.e. S3 and S4) appeared to maintain closer contact with the water table. For example, WTD at $\mathrm{S} 3$ and $\mathrm{S} 4$ remained only a few $\mathrm{cm}$ below the surface through the winter while S1 had the second greatest amount of standing water after S2. During the winter, the surface of the peatland was typically frozen until late April except for occasional warm periods when the wetland surface became flooded with melt water from surface snow and ice. The temporal variations in WTD at all microsites were much greater in 2008 than in 2009. For example, the extreme rain events of 20 and 21 August 2008 resulted in a total precipitation of $75 \mathrm{~mm}$ which caused S1 WTD to 
Table 1 Average, minimum and maximum values of air and peat temperature, water table depth and total precipitation at the main weather station in 2008 and 2009. The summer period refers to June 1 to August 31

\begin{tabular}{lccccc}
\hline & 2008 & & \multicolumn{2}{l}{2009} & \\
\cline { 2 - 3 } \cline { 5 - 6 } & Annual (min, max) & Summer (min, max) & & Annual (min, max) & Summer (min, max) \\
\hline Air temperature $\left({ }^{\circ} \mathrm{C}\right)$ & $9.5(-13.8,34.5)$ & $18.2(1.8,34.5)$ & & $8.3(-22.9,33.5)$ & $17.3(0.0,33.5)$ \\
Peat temperature at the $5 \mathrm{~cm}$ depth $\left({ }^{\circ} \mathrm{C}\right)$ & $10.0(-0.5,22.2)$ & $18.6(12.7,22.2)$ & & $9.2(-0.6,21.0)$ & $17.2(10.8,21.0)$ \\
Water table depth $(\mathrm{cm})$ & $-5.3(-25.7,11.0)$ & $-15.8(-25.7,-5.6)$ & & $-4.0(-11.1,2.1)$ & $-4.0(-6.8,-1.2)$ \\
Total precipitation $(\mathrm{mm})$ & 713.2 & 253.2 & 705.2 & 231.8 \\
\hline
\end{tabular}

increase by about $30 \mathrm{~cm}$. Peat temperature at $5 \mathrm{~cm}$ depth was similar among microsites and showed only small differences between the 2 years reflecting the small interannual difference in air temperature (Fig. 2a, Tables 1 and 2).

Environmental controls on $R_{e c o}$

On average, measured $R_{e c o}$ and derived $R_{\text {ref }}$ were greatest in S1, the microsite with greatest vascular plant LAI (Table 2). However, despite a $22 \mathrm{~cm}$ difference in minimum WTD between the 2 years at the S1 plots, there was no significant difference in measured $R_{e c o}$ or the $R_{\text {ref }}$ and $E_{o}$ parameters for the Lloyd and Taylor (1994) $R_{\text {eco }}$-temperature relationship (Eq. 2) (Fig. 3, Table 2). The Sphagnum-covered microsite $\mathrm{S} 4$ also showed no significant change in the relationship between $R_{\text {eco }}$ and temperature with a $7 \mathrm{~cm}$ difference in minimum WTD between the 2 years. For the remaining two microsites that did show a change in
Fig. 2 Seasonal courses of simulated $5 \mathrm{~cm}$ peat temperature $\left(T_{5}\right)(\mathbf{a})$ and water table depth $(W T D)$ and measured daily total precipitation (b) in 2008-2009 for all microsites

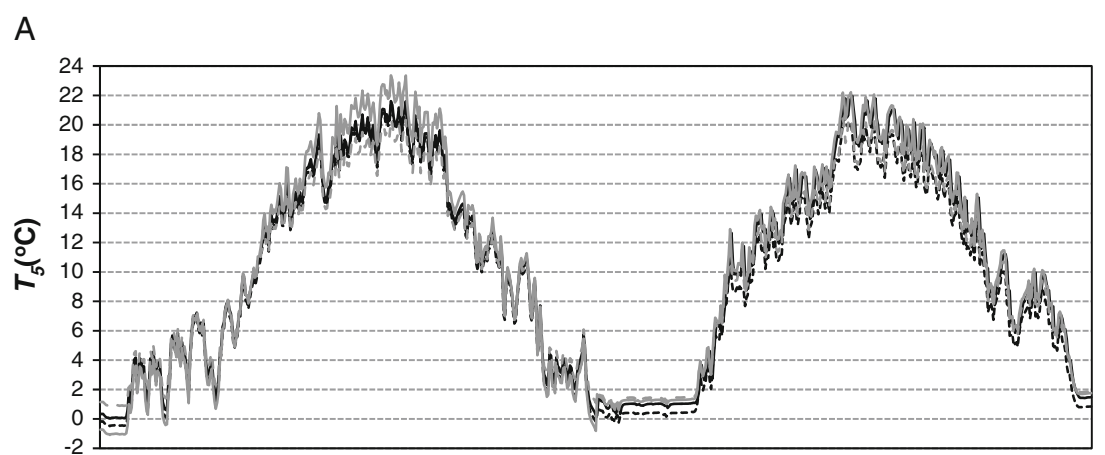

B

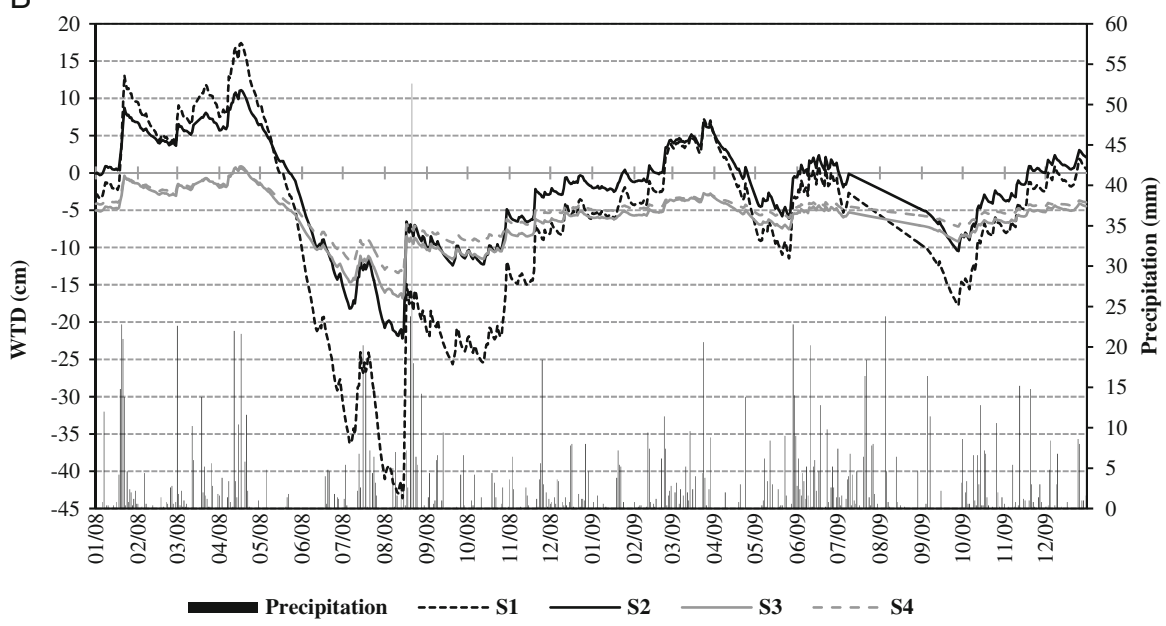




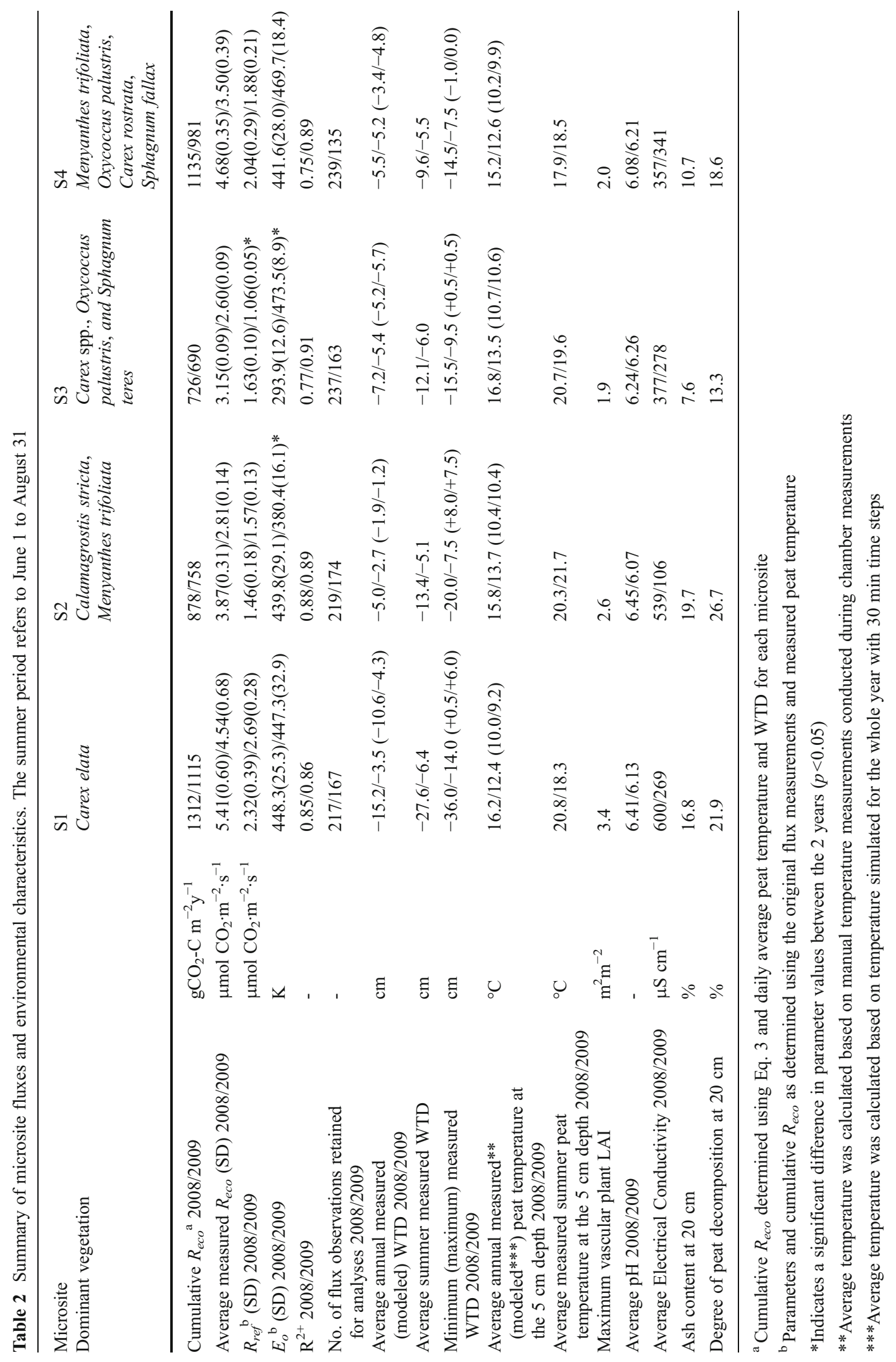


their $R_{\text {eco }}$-temperature relationship, the patterns were not consistent. Microsite S3 experienced a difference in minimum WTD of only $6 \mathrm{~cm}$ and a difference in both $R_{r e f}$ and in $E_{o}$ between years where $R_{r e f}$ was significantly greater while $E_{o}$ was lower in the drier year (Table 2 ). Consequently $R_{\text {eco }}$ was less sensitive to temperature in drier 2008 with lower $R_{e c o}$ at high temperatures and higher $R_{\text {eco }}$ at low temperatures (Fig. 3). This microsite was dominated by a Sphagnum cover with a relatively sparse overstory of Carex spp. and Oxycoccus palustris resulting in the lowest maximum vascular plant LAI (1.9) of all the microsites and with the least amount of peat decomposition at $20 \mathrm{~cm}$. The microsite dominated by Carex spp, M. trifoliata, and other herbs but with relatively little Sphagnum understory (S2) had the greatest degree of peat decomposition and greater $E_{o}$ in the dry year with no change in $R_{\text {ref }}$ (Fig. 3, Table 2).

Spatial relationships among measures of respiration, its sensitivity to temperature and plot characteristics are examined and compared between years using a correlation matrix (Table 3 ). $R_{\text {eco }}$ was significantly correlated to LAI in both years (Fig. 4a) and to WTD during the dry year. In the dry year (2008), plots with greater LAI tended to have deeper WTD. Of these correlations, only the one with LAI remained significant in wetter 2009. Instead there were significant negative correlations between $R_{e c o}$ (and also with $R_{r e f}$ ) with measures of peat temperature perhaps due to slightly less warming of the peat underlying the densely vegetated plots. Only annual measured WTD correlated significantly with $R_{\text {ref }}$ in the dry year (2008) again indicating greatest respiration for the driest plots (Fig. 4b) which also tended to be the plots with greater LAI. Consequently, LAI significantly correlated with $R_{r e f}$ in the wet year (2009) as it did for $R_{\text {eco }}$. Spatial variations in $E_{o}$ were minimal during the wet year but still correlated with peat characteristics (Fig. 4c) and annual WTD while in the dry year, variations in $E_{o}$ were relatively large and LAI became important. Due to the large change in $E_{o}$ between years for S3, this measure of respiration's sensitivity to peat temperature correlated positively with ash content and degree of decomposition in the dry year (with no relationship to WTD) while in the wet year (2009), $E_{o}$ increased with decreasing peat ash content and degree of decomposition, which also negatively correlated with annual measured WTD although this only varied from -1 to $-7 \mathrm{~cm}$.

For at least two of the four microsites, temporal variations in WTD appeared to have a substantial impact on respiration rates and as a result, a combined temperature and WTD model was used to estimate daily $R_{e c o}$ and compute annual $R_{e c o}$. This model explained between $90 \%$ and $96 \%$ of the temporal variation in a test set of daily average $R_{\text {eco }}$ (Table 4 ). For the two microsites where the $R_{e c o}$-temperature
Fig. 3 Measured $R_{\text {eco }}$ and peat temperature $\left(T_{5}\right)$ at the $5 \mathrm{~cm}$ depth in 2008 (circles) and 2009 (solid triangles) for the four microsites. The associated Lloyd and Taylor (1994) exponential function is shown for 2008 (solid line) and 2009 (dashed line). Parameters for this function are given in Table 2
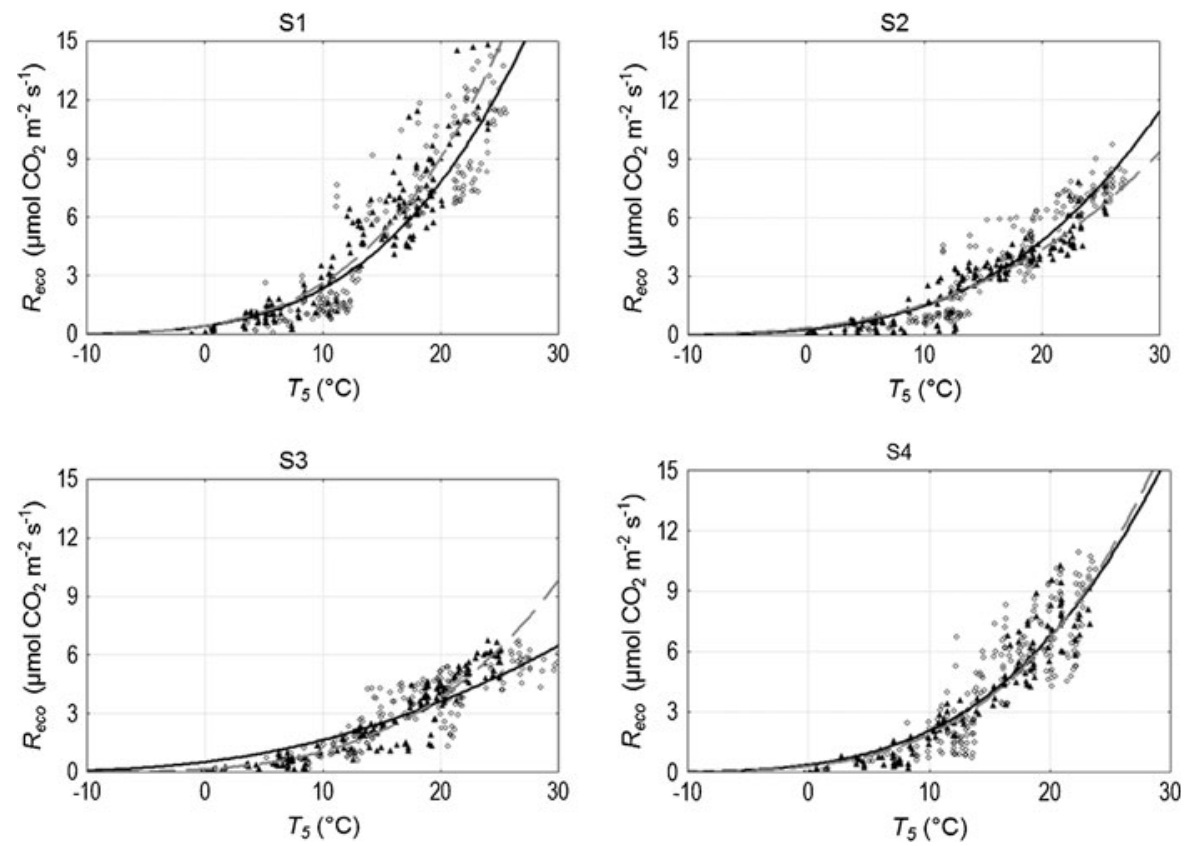
Table 3 Matrix with Pearson correlation coefficients for measured $R_{\text {eco }}$, temperature response model parameters and measured ancillary data for each plot within the 4 microsites $(n=12) .2008$ results are listed above those for 2009

\begin{tabular}{|c|c|c|c|c|c|c|c|c|c|c|c|c|}
\hline $\begin{array}{l}2008 \\
2009\end{array}$ & $\begin{array}{l}\mathrm{R}_{\text {eco }} \\
\text { avg }\end{array}$ & $\mathrm{R}_{\mathrm{ref}}$ & $\mathrm{E}_{\mathrm{o}}$ & $T_{5}$ annual & $T_{5}$ summer & $\begin{array}{l}\text { WTD } \\
\text { annual }\end{array}$ & $\begin{array}{l}\text { WTD } \\
\text { summer }\end{array}$ & Max LAI & $\mathrm{p}$ & $\mathrm{R}$ & $\mathrm{pH}$ & $\mathrm{EC}$ \\
\hline \multirow[t]{2}{*}{$\mathrm{R}_{\text {eco avg }}$} & \multirow[t]{2}{*}{1.00} & $0.88 * *$ & $0.63 *$ & -0.42 & -0.25 & $-0.60 *$ & $-0.58^{*}$ & $0.68^{*}$ & 0.39 & 0.37 & 0.04 & 0.52 \\
\hline & & $0.97 * * *$ & 0.21 & $-0.86 * * *$ & $-0.60 *$ & -0.08 & -0.32 & $0.72 * *$ & 0.29 & 0.22 & -0.24 & 0.19 \\
\hline \multirow[t]{2}{*}{$\mathrm{R}_{\text {ref }}$} & & 1.00 & 0.20 & -0.19 & -0.24 & $-0.62 *$ & -0.50 & 0.46 & -0.01 & -0.06 & -0.18 & 0.28 \\
\hline & & & 0.00 & $-0.93 * * *$ & -0.56 & 0.07 & -0.24 & $0.81 * *$ & $0.48 *$ & 0.42 & -0.31 & 0.09 \\
\hline \multirow[t]{2}{*}{$\mathrm{E}_{\mathrm{o}}$} & & & 1.00 & $-0.67^{*}$ & -0.28 & -0.19 & -0.31 & $0.54^{*}$ & $0.70^{* *}$ & $0.76^{* *}$ & 0.22 & 0.45 \\
\hline & & & & -0.03 & -0.37 & $-0.83 * * *$ & -0.46 & -0.32 & $-0.80 * *$ & $-0.81 * *$ & 0.28 & $0.63 *$ \\
\hline \multirow[t]{2}{*}{$T_{5}$ annual } & & & & 1.00 & $0.78^{* *}$ & -0.30 & -0.25 & 0.11 & -0.25 & -0.43 & 0.39 & 0.10 \\
\hline & & & & & $0.59^{*}$ & -0.08 & 0.14 & $-0.68 *$ & -0.46 & -0.46 & 0.34 & -0.17 \\
\hline \multirow[t]{2}{*}{$T_{5}$ summer } & & & & & 1.00 & -0.49 & -0.57 & 0.48 & 0.28 & 0.09 & $0.71 *$ & 0.55 \\
\hline & & & & & & 0.43 & 0.40 & -0.29 & 0.11 & 0.14 & -0.24 & -0.41 \\
\hline \multirow{2}{*}{$\begin{array}{l}\text { WTD } \\
\text { annual }\end{array}$} & & & & & & 1.00 & $0.95 * * *$ & $-0.80 * *$ & -0.21 & -0.03 & -0.33 & $-0.63^{*}$ \\
\hline & & & & & & & $0.73 * *$ & 0.25 & $0.78^{*} *$ & $0.83 * * *$ & -0.53 & $-0.76^{* *}$ \\
\hline \multirow{2}{*}{$\begin{array}{l}\text { WTD } \\
\text { summer }\end{array}$} & & & & & & & 1.00 & $-0.90 * * *$ & -0.45 & -0.28 & $-0.52 *$ & $-0.77 * *$ \\
\hline & & & & & & & & -0.36 & 0.20 & 0.36 & -0.21 & -0.48 \\
\hline \multirow[t]{2}{*}{ Max LAI } & & & & & & & & 1.00 & $0.72 * *$ & $0.58^{*}$ & $0.68^{*}$ & $0.90^{* * *}$ \\
\hline & & & & & & & & & $0.72 * *$ & $0.58^{*}$ & -0.39 & -0.20 \\
\hline \multirow[t]{2}{*}{$\mathrm{p}$} & & & & & & & & & 1.00 & $0.97 * * *$ & $0.74 *$ & $0.83 * *$ \\
\hline & & & & & & & & & & $0.97 * * *$ & 0.36 & -0.56 \\
\hline \multirow[t]{2}{*}{$\mathrm{R}$} & & & & & & & & & & 1.00 & 0.61 & $0.71 * *$ \\
\hline & & & & & & & & & & & -0.56 & -0.55 \\
\hline \multirow[t]{2}{*}{$\mathrm{pH}$} & & & & & & & & & & & 1.00 & $0.80 * *$ \\
\hline & & & & & & & & & & & & 0.10 \\
\hline $\mathrm{EC}$ & & & & & & & & & & & & 1.00 \\
\hline
\end{tabular}

*Correlation was significant at the $\alpha=0.05$ level

$* * \alpha=0.01$

$* * * \alpha=0.001$

$R_{\text {eco avg. }}$ average measured ecosystem respiration $\left(\mu \mathrm{mol} \mathrm{CO} \mathrm{CO}^{-2} \cdot \mathrm{s}^{-1}\right)$

$R_{\text {ref }}$ reference respiration at $10{ }^{\circ} \mathrm{C}\left(\mu \mathrm{mol} \mathrm{CO} \mathrm{CO}_{2} \cdot \mathrm{m}^{-2} \cdot \mathrm{s}^{-1}\right)$

$E_{o}$ activation energy $(\mathrm{K})$

$T_{5}$ average measured peat temperature at the $5 \mathrm{~cm}$ depth $\left({ }^{\circ} \mathrm{C}\right)$

WTD average measured water table depth $(\mathrm{cm})$

$L A I$ maximum leaf area index

$p$ ash content (\%)

$R$ degree of peat decomposition (\%)

$E C$ electrical conductivity $\left(\mu S \cdot \mathrm{cm}^{-1}\right)$

Note that $R_{\text {eco avg }}$ and $T_{5}$ seasonal and annual averages are computed from the original meaurements used to derive $R_{r e f}$ and $E_{o}$ and are thus not strictly independent of these model parameters

relationship did not vary between the 2 years (S1 and S4), the model coefficient associated with WTD effects $\left(b_{2}\right)$ was not significant $(p>0.05)$ as expected, although the coefficient associated with an interaction between daily WTD and temperature $\left(b_{3}\right)$ was significant. On an annual basis, cumulative $R_{\text {eco }}$ was estimated for the four microsites to be between 5 and $18 \%$ greater in the warmer year with deeper WTD (Table 2). 

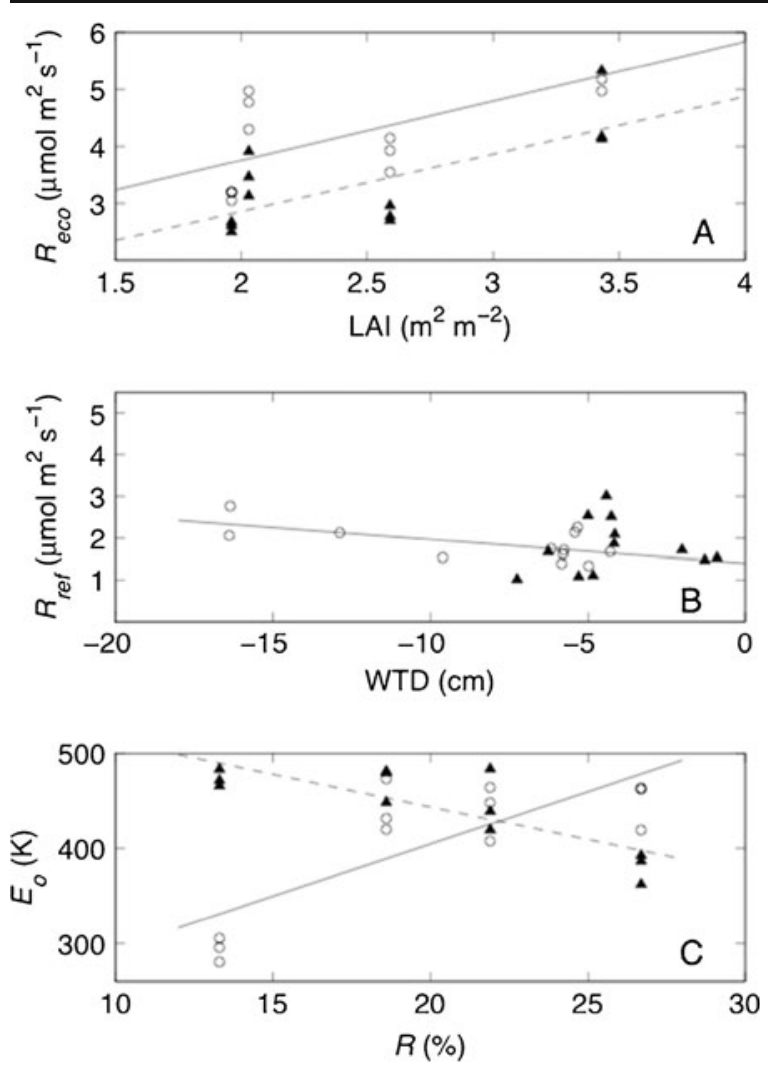

Fig. 4 Selected relationships between the plot-specific (a) average measured $R_{e c o}$ vs. maximum microsite vascular plant leaf area index $(L A I),(\mathbf{b})$ reference respiration $\left(R_{r e f}\right)$ at $10.0^{\circ} \mathrm{C}$ vs. average measured water table depth $(W T D)$ for the full annual period and (c) temperature sensitivity of $R_{\text {eco }}$ expressed by model parameter $\left(E_{o}\right)$ and degree of peat decomposition at $20 \mathrm{~cm}$ depth $(R)$ for 2008 (open circles) and 2009 (solid triangles). Linear relationships are shown when significant (Table 3) using a solid line for 2008 and dashed line for 2009

\section{Discussion}

Our aim was to reveal the factors that influenced the relationships between $R_{e c o}$ and peat temperature over time and among different vegetation community groups in a relatively wet peatland that experienced contrasting WTD patterns over a two-year period. Our results confirm that temporal variations in $R_{\text {eco }}$ are largely well described by variations in temperature. This finding is in agreement with many other peatland studies (e.g. Bubier et al. 2003; Silvola et al. 1996; Riutta et al. 2007; Chimner and Cooper 2003; Lafleur et al. 2005; Mäkiranta et al. 2009; Sulman et al. 2009; Juszczak et al. 2010, 2012) as well as studies carried out in upland ecosystems such as forests (e.g. Griffis et al. 2004; Knohl et al. 2008; Pavelka et al. 2007) and agricultural systems (e.g. Falge et al. 2002; Lohila et al. 2003; Suleau et al. 2011).

Although we found an increase in daily $R_{\text {eco }}$ with deepening WTD at all microsites (not shown), the confounding effect of simultaneously increasing peat temperatures made it difficult to attribute this response to increasing rates of aerobic respiration. Instead, we examined the influence of deeper WTD on the relationships between $R_{e c o}$ and peat temperature. The results were inconsistent among the microsites with two microsites showing no WTD influence, one microsite showing an increase in temperature sensitivity and one microsite showing a decrease in temperature sensitivity offset to some extent with an increase in $R_{\text {ref }}$.

As discussed earlier, a number of peatland studies have not found a strong response of $R_{\text {eco }}$ to variations in WTD (e.g. Updegraff et al. 2001; Lafleur et al. 2005; Chivers et al. 2009; Dimitrov et al. 2010). Lafleur et al. (2005) hypothesized that variations in WTD may have a greater impact in peatlands where the water table is closer to the surface. In relatively dry peatlands with typically low water levels, variations in WTD well below the surface would result in little change in soil moisture conditions in the highly porous upper peat layers where potential respiration rates and sensitivity to moisture conditions are highest. Our results did show that $R_{\text {eco }}$ was relatively insensitive to WTD at the microsite with the deepest water table (S1) but this was also the case for the relatively wet microsite S4 where minimum WTD was only 7 to $14 \mathrm{~cm}$ below the surface.

Plant community characteristics appeared to have influenced both the spatial variations in the magnitude of $R_{\text {eco }}$ and its sensitivity to temperature as demonstrated by the positive correlation with LAI for $R_{\text {eco, }}$, $R_{r e f}$, and $E_{o}$ in either the dry or wet year. The amount of vegetation biomass and its productivity is expected to influence $R_{\text {eco }}$ through both direct rates of autotrophic respiration above and below ground and through greater litter and rhizosphere inputs that enhance heterotrophic respiration (Raich and Schlesinger 1992; Fenner et al. 2004; Ward et al. 2010). The influence of plant community characteristics on $R_{e c o}$ was also apparent on the Sphagnum-dominated microsite (S3) that had peat with a relatively lower degree of decomposition and lower average $R_{\text {eco }}$ than other microsites. This is expected from studies that show Sphagnum to be a relatively recalcitrant component of peat (Freeman et al. 1993; Evans et al. 2002; Robroek et 
Table 4 Multiple regression coefficients for Eq. 3, regression statistics performance expressed by RMSE and NRMSE (\%), coefficients of determination $\left(r^{2}\right), p$ values and number of measurements included in analyses $(n)$ for the relationship between average daily $R_{\text {eco }}$, average daily WTD and average daily $5 \mathrm{~cm}$ peat temperature. Values in brackets correspond to standard deviations of the estimated regressions coefficients. Values correspond to the entire data set from 2008 to 2009

\begin{tabular}{|c|c|c|c|c|}
\hline & $\mathrm{S} 1$ & $\mathrm{~S} 2$ & S3 & $\mathrm{S} 4$ \\
\hline \multirow[t]{2}{*}{$\widehat{b}_{0}$} & $-1.247(0.46)$ & $-1.219(0.24)$ & $-0.840(0.25)$ & $-1.182(0.59)$ \\
\hline & $p=0.064$ & $p<0.001$ & $p=0.003$ & $p=0.148$ \\
\hline \multirow[t]{2}{*}{$\widehat{b}_{1}$} & $0.440(0.044)$ & $0.290(0.021)$ & $0.266(0.017)$ & $0.369(0.041)$ \\
\hline & $p<0.001$ & $p<0.001$ & $p<0.001$ & $p<0.001$ \\
\hline \multirow[t]{2}{*}{$\widehat{b}_{2}$} & $0.120(0.047)$ & $0.163(0.034)$ & $0.109(0.042)$ & $0.280(0.125)$ \\
\hline & $p=0.072$ & $p=0.001$ & $p=0.024$ & $p=0.086$ \\
\hline \multirow[t]{2}{*}{$\widehat{b}_{3}$} & $-0.00809(0.00266)$ & $-0.01178(0.00194)$ & $-0.00414(0.00203)$ & $-0.02211(0.00720)$ \\
\hline & $p=0.003$ & $p=0.012$ & $p=0.151$ & $p=0.032$ \\
\hline RMSE* & 1.49 & 0.75 & 0.56 & 1.19 \\
\hline RMSE** & 1.19 & 0.63 & 0.48 & 0.95 \\
\hline NRMSE(\%)* & 11.37 & 9.31 & 10.21 & 12.94 \\
\hline $\operatorname{NRMSE}(\%)^{* *}$ & 10.73 & 7.43 & 9.69 & 11.36 \\
\hline$r^{2 *}$ & 0.86 & 0.91 & 0.94 & 0.87 \\
\hline$r^{2 * *}$ & 0.90 & 0.95 & 0.96 & 0.92 \\
\hline$n^{*}$ & 38 & 40 & 37 & 39 \\
\hline$n^{* *}$ & 16 & 16 & 16 & 16 \\
\hline
\end{tabular}

*values refer to a randomly selected subset of $70 \%$ of data which were used for the model development

**values refer to the remaining subset of $30 \%$ of data which were used to validate the model

al. 2007). Further, the composition of plant species and peatland hydrological conditions are tightly coupled (Dimitrov et al. 2010; Riutta et al. 2007; Weltzin et al. 2003). For example, in the densely vegetated S1 microsite, water table may have been particularly low in 2008 due to high rates of transpiration from these areas. Further, the elevation of the peat surface may have been relatively high at this microsite due to the tufted nature of the sedges and proximity to the peatland's edge. However, sedges are known to root deeply (Murphy and Moore 2010) and were unlikely to experience drought stress such that rates of autotrophic respiration may have varied little between years while increasing microbial respiration in the deep peat may have been offset by reduced microbial respiration in the desiccated surface layers, as described by Dimitrov et al. (2010). Although the exact contribution of plant derived respiration to $R_{\text {eco }}$ in our Rzecin wetland plots is unknown, it may vary from $35 \%$ to $57 \%$ as measured by pulse ${ }^{14} \mathrm{C}$ labeling by Crow and Wieder (2005). Riutta et al. (2007) estimated the contribution of autotrophic respiration to $R_{\text {eco }}$ to be close to $46 \%$ while Moore et al. (2002) and Frolking et al.
(2002) assumed this value to be close to $50 \%$. The other microsite to show no significant influence of WTD on $R_{\text {eco }}$ temperature sensitivity was the S4 microsite which had low vascular plant LAI, but had a full Sphagnum cover such that total LAI would have approached a value of 3.0 (assuming an LAI of 1.0 for the Sphagnum carpet), similar to that of microsite S1. Microsite S4 also had the second greatest measured $R_{e c o}$ and the second highest annual estimates after S1. These results may have been due to relatively small fluctuations in WTD maintaining optimum conditions for both autotrophic and heterotrophic respiration. This microsite was near the centre of the peatland and the floating carpet of peat may have maintained better contact with the fluctuating water table when compared to sites closer to the edge of the wetland. However, no measures of surface position were available to confirm this. The WTD threshold at which a further decrease in WTD does not increase respiration rates seems to be site specific and depends on the average wetness of the peatland surface. Riutta et al. (2007) suggested this threshold WTD to be approximately $-0.14 \mathrm{~m}$ while Chimner and Cooper (2003) 
suggested $-0.10 \mathrm{~m}$. These threshold WTD are both for relatively wet peatlands and happen to be similar to the minimum WTD observed at microsite S4 during the two-year study such that the WTD at S4 may have been ideal for maximum $R_{\text {eco }}$.

In the two microsites which did have varying sensitivity to temperature between the two study years, the $E_{o}$ parameter decreased from $439 \mathrm{~K}$ to $380 \mathrm{~K}$ (S2) and increased from $293 \mathrm{~K}$ to $473 \mathrm{~K}$ (S3) between the drier 2008 and wetter 2009. In the original Lloyd and Taylor (1994) model, $E_{o}$ was fixed at $308.56 \mathrm{~K}$. The rates of $E_{o}$ estimated for our microsites are in the range of values found by Drösler (2005) for peatlands in the southern part of Germany. The lowest $E_{o}$ was found on a degraded drained bog heathland $(258 \mathrm{~K})$, while the highest value of $E_{o}$ was found for natural peatlands dominated by Sphagnum mosses (499 K) with an average of $360 \mathrm{~K}$ for natural peatlands (Drösler 2005). Thus the low $E_{o}$ at $\mathrm{S} 3$ in 2008 was not remarkably low but may have been related to the nature of the peat at this microsite, which had the lowest degree of peat decomposition of all the sites. The activation energy of soil organic matter decomposition increases with decreasing lability of organic matter (Conant et al. 2008) and increasing molecular complexity of the peat substrate. The relative rate of decomposition of recalcitrant organic matter is highly sensitive to temperature (Davidson and Janssens 2006). However, in an absolute sense, the increase in respiration with increasing temperature is usually much greater for more labile compounds. The factor by which $R_{e c o}$ increases for a $10{ }^{\circ} \mathrm{C}$ increase in temperature $\left(\mathrm{Q}_{10}\right)$ (calculated from Eq. 3 and the values in Table 2 at $10^{\circ} \mathrm{C}$ and $20^{\circ} \mathrm{C}$ ) was much lower in 2008 at 2.2 vs. 3.6 in 2009 at the S3 microsite. These differences were associated with a modest difference of $6 \mathrm{~cm}$ in minimum WTD but may still have crossed the critical WTD threshold whereby dryness in the surface peat limits microbial activities (Flanagan and Johnson 2005; Reichstein et al. 2003). These results for S3 were also in agreement with those of Mäkiranta et al. (2009) who found that $E_{o}$ increased from $200 \mathrm{~K}$ to $800 \mathrm{~K}$ with rising WTD. They suggested that water level conditions may affect the temperature sensitivity of peat respiration mainly via changes in microbial community structure. This explanation may be even more important for recalcitrant substrates and specialized microbial communities needed to breakdown these compounds (Jaatinen et al. 2007, 2008).
The explanation for the S2 microsite's greater temperature sensitivity $\left(E_{o}=440 \mathrm{~K}, \mathrm{Q}_{10}=3.3\right)$ in the year with deeper minimum WTD $(-20 \mathrm{~cm})$ vs. the wetter year $\left(E_{o}=380, \mathrm{Q}_{10}=2.8, \mathrm{WTD}=-7 \mathrm{~cm}\right)$ may simply be due to a shift to more efficient aerobic vs. anaerobic respiration within the peat profile. This site also had a relatively high vascular LAI, the greatest degree of peat decomposition but also had the lowest electrical conductivity in the wet year. Electrical conductivity of the subsurface peat water is often used as an indicator of nutrient status (Pfadenhauer 1997) and is important for plant productivity and mineralization processes (Drösler 2005). Thus, in 2009, there may have also been nutrient limitations to both microbial activity and plant growth with further feedback effects on both autotrophic and rhizospheric respiration processes.

In this study, we concluded that peat temperature and WTD were important microsite-specific drivers of $R_{e c o}$ with significant interactions at most microsites. Other researchers have integrated peat temperature and WTD into $R_{\text {eco }}$ models in the past with complex exponential models rather than the simple linear regression used here (e.g. Mäkiranta et al. 2009; Riutta et al. 2007; Chivers et al. 2009). Our model, although entirely empirical, showed success in describing the temporal variations in daily $R_{\text {eco }}$ within a microsite and clearly demonstrated that despite varying changes in the temperature- $R_{\text {eco }}$ relationship between years, relatively consistent increases in $R_{\text {eco }}$ (between $5 \%$ and $18 \%$ ) occurred in the warmer drier year.

\section{Conclusions}

Four microsites with different vegetation and peat characteristics but all within the same temperate peatland demonstrated substantial variations in $R_{\text {eco }}$ and its response to temperature. The sensitivity of $R_{\text {eco }}$ to peat temperature increased at one microsite, decreased at another and remain unchanged in the two other microsites over a 2 year period with different WTD conditions. Spatial variations in the $R_{e c o^{-}}$temperature relationships could be correlated to a number of vegetation and peat characteristics with some differences between years. These results emphasized the importance of vegetation composition on autotrophic and heterotrophic respiration processes at the micro-scale as it affects peat chemical and physical properties, water movement and nutrient status. Consequently, 
for a heterogeneous peatland such as the Rzecin peatland, spatial heterogeneity and the dynamic links between hydrology and vegetation would need to be addressed within biogeochemical models to obtain realistic estimates of $R_{e c o}$ in a changing climate.

Acknowledgements We would like to thank the anonymous reviewers for challenging questions and suggestions, which helped improve the manuscript. We would like to express our gratitude to Prof. Xuhui Lee from Yale University and Dr Rachhpal Jassal from University of British Columbia for giving very useful comments and corrections to our manuscript. Funding was provided by the EU FP6 Project "GREENFLUX", MTKD-CT-2006-042445, "Micrometeorological techniques for in-situ measurements of greenhouse gases exchange", EU FP6 Project NITROEUROPEIP, GOCE-CT-2006-017841 "The nitrogen cycle and its influence on the European greenhouse gas balance" and EU FP7 Project GHG-Europe FP7-CP-IP- 244122-2010 "Greenhouse gas management in European land use systems".

Open Access This article is distributed under the terms of the Creative Commons Attribution License which permits any use, distribution, and reproduction in any medium, provided the original author(s) and the source are credited.

\section{References}

Blodau C, Basiliko N, Moore TR (2004) Carbon turnover in peatland mesocosms exposed to different water table levels. Biogeochemistry 67:331-351

Bubier J, Crill P, Mosedale A, Frolking S, Linder E (2003) Peatland responses to varying interannual moisture conditions as measured by automatic $\mathrm{CO}_{2}$ chambers. Global Biogeochem Cycles 17(2). doi:10.1029/2002GB0019

Chimner R, Cooper DJ (2003) Influence of water table levels on $\mathrm{CO}_{2}$ emissions in a Colorado subalpine fen: an in situ microcosm study. Soil Biol Biochem 35:345-351

Chivers MR, Turetsky MR, Waddington JM, Harden JW, McGuire AD (2009) Effects of experimental water table and temperature manipulations on ecosystem $\mathrm{CO}_{2}$ fluxes in an Alaskan rich fen. Ecosystems 12:1329-1342

Chojnicki BH, Michalak M, Acosta M, Juszczak R, Augustin J, Droesler M, Olejnik J (2010) Measurements of carbon dioxide fluxes by chamber method at Rzecin wetland ecosystem in Poland. Pol J Environ Stud 19(2):283-291

Christiansen JR, Korhonen J, Juszczak R, Giebels M, Pihlatie M (2011) Assessing the effects of chamber placement, manual sampling and headspace mixing on $\mathrm{CH}_{4}$ fluxes in a laboratory experiment. Plant Soil 343:171-185

Clymo RS (1983) Peat. In: Gore AJP (ed) Ecosystems of the world 4A mires: Swamp, bog, fen and moor. General studies. Elsevier, Amsterdam, pp 159-224

Conant R, Drijber RA, Haddix ML, Parton WJ, Paul EA, Plante AF, Six J, Steinweg JM (2008) Sensitivity of organic matter decomposition to warming varies with its quality. Glob Chang Biol 14:868-877
Crow SE, Wieder RK (2005) Sources of $\mathrm{CO}_{2}$ emission from a northern peatland: root respiration, exudation, and decomposition. Ecology 86:1825-1834

Davidson EA, Janssens IA (2006) Temperature sensitivity of soil carbon decomposition and feedbacks to climate change. Nature 440:165-173

Dimitrov DD, Grant RF, Lafleur PM, Humpreys ER (2010) Modeling the effects of hydrology on ecosystem respiration at Mer Bleue bog. J Geophys Res 115:1-24

Drösler M (2005) Trace gas exchange and climatic relevance of bog ecosystem, Southern Germany. PhD Dissertation, Lehrstuhl für Vegetationsokologie, Department für Ökologie, Technischen Universität München, pp 182

Drösler M, Freibauer A, Christensen T, Friborg T (2006) Observations and status of peatland greenhouse gas emissions in Europe. In: Dolman AJ, Valentini R, Freibauer A (eds) The continental- scale greenhause gas balance of Europe, Ecol Stud 203:243-261

Evans CD, Freeman C, Monteith DT, Reynolds B, Fenner N (2002) Terrestrial export of organic carbon. Nature 415:862

Falge E, Baldocchi D, Tenhunen J, Aubinet M, Bakwin P, Berbigier P, Bernhofer C, Burba G, Clement R, Kenneth JD, Elbers JA, Goldstein AH, Grelle A, Granier A, Guđmundsson J, Hollinger D, Kowalski AS, Katul G, Law BE, Malhi Y, Meyers T, Monson RK, Munger JW, Oechel W, Kyaw Tha Paw U, Pilegaard K, Rannik Ü, Rebmann C, Suyker A, Valentini R, Wilson K, Wofsy S (2002) Seasonality of ecosystem respiration and gross primary production as derived from FLUXNET measurements. Agric For Meteorol 113:53-74

Fenner N, Ostle N, Freeman C, Sleep D, Reynolds B (2004) Peatland carbon efflux partitioning reveals that Sphagnum photosynthate contributes to the DOC pool. Plant Soil 259:345-354

Flanagan LB, Johnson BG (2005) Interacting effects of temperature, soil moisture and plant biomass production on ecosystem respiration in a northern temperate grassland. Agric For Meteorol 130:237-253

Freeman C, Lock MA, Reynolds B (1993) Impacts of climatic change on peatland hydrochemistry; a laboratory based experiment. Chem Ecol 8:49-59

Frolking SE, Crill P (1994) Climate controls on temporal variability of methane flux from a poor fen in southeastern New Hampshire: measurements and modeling. Global Biogeochem Cycles 8:385-397

Frolking S, Roulet NT, Moore TR, Lafleur PM, Bubier JL, Crill PM (2002) Modeling the seasonal to annual carbon balance of Mer Bleue bog, Ontario, Canada. Global Biogeochem Cycles 16. doi:10.1029/2001GB1457

Gorham E (1991) Northern peatlands: role in the carbon cycle and probable responses to climatic warming. Ecol Appl 1:182-195

Griffis TJ, Black AT, Gaumont-Guay D, Drewitt GB, Nesic Z, Barr AG, Morgenstern K, Kljun N (2004) Seasonal variation and partitioning of ecosystem respiration in a southern boreal aspen forest. Agric For Meteorol 125:207-223

Jaatinen K, Fritze H, Laine J, Laiho R (2007) Effects of shortand long-term water-level drawdown on the populations and activity of aerobic decomposers in a boreal peatland. Glob Chang Biol 13:491-510

Jaatinen K, Laiho R, del Castillo U, Minkkinen K, Pennanen T, Penttilä T, Fritze H (2008) Responses of aerobic microbial 
communites and soil soil respiration to water-level drawdown in a northern boreal fen. Environ Microbiol 10:339-353

Joosten H, Clarke D (2002) Wise use of mires and peatlands: background and principles including a framework for decision-making. International Peat Society, 304 pp ISBN: 9519774483

Juszczak R, Acosta M, Michalak M, Chojnicki B, Urbaniak M, Drösler M, Augustin J, Olejnik J (2010) Night-Time $\mathrm{CO}_{2}$ chamber measurements in peatland ecosystem in Poland. In Chojnicki BH (ed) Atmospheric heat and mass exchange research. Acta Agrophysica 179:113-131

Juszczak R, Acosta M, Olejnik J (2012) Comparison of daytime and nighttime ecosystem respiration measured by the closed chamber technique on temperate mire in Poland. Pol J Environ Stud 21(3):643-658

Knohl A, Soe ARB, Kutsch WL, Göckede M, Buchman N (2008) Representative estimates of soil and ecosystem respiration in an old beech forest. Plant Soil 302:189-202

Lafleur PM, Moore TR, Roulet NT, Frolking S (2005) Ecosystem respiration in a cool temperate bog depends on peat temperature but not water table. Ecosystems 8:619-629

Livingston GP, Hutchinson GL (1995) Enclosure-based measurement of trace gas exchange: Applications and sources of error. In: Matson PA, Harriss RC (eds) Biogenic trace gases: Measuring emissions from soil and water. Blackwell Science, Cambridge, pp 14-50

Lloyd J, Taylor JA (1994) On the temperature dependence of soil respiration. Funct Ecol 8:315-323

Lohila A, Aurela M, Regina K, Laurila T (2003) Soil and total ecosystem respiration in agricultural fields: effect of soil and crop type. Plant Soil 251:303-317

Mäkiranta P, Laiho R, Fritze H, Hytönen J, Laine J, Minkkinen K (2009) Indirect regulation of heterotrophic peat soil respiration by water level via microbial community structure and temperature sensitivity. Soil Biol Biochem 41:695-703

Michalak M, Juszczak R, Acosta M, Chojnicki B, Drösler M, Augustin J, Olejnik J (2010) Comparison of observed and modeled daily ecosystem respiration $\left(R_{\text {eco }}\right)$ and net ecosystem exchange (NEE). In Chojnicki BH (ed) Atmospheric heat and mass exchange research. Acta Agrophysica 179:41-58

Moore TR, Dalva M (1993) The influence of temperature and water table position on carbon dioxide and methane emissions from laboratory columns of peatland soil. J Soil Sci 44:651-664

Moore T, Dalva M (1997) Methane and carbon dioxide exchange potentials of peat soils in aerobic and anaerobic laboratory incubations. Soil Biol Biochem 29:1157-1164

Moore TR, Knowles R (1989) The influence of water table levels on methane and carbon dioxide emissions from peatland soil. Can J Soil Sci 69:33-38

Moore T, Bubier J, Lafleur P, Frolking S, Roulet N (2002) Plant biomass, production and $\mathrm{CO}_{2}$ exchange in an ombrotrophic bog. J Ecol 90:25-36

Murphy MT, Moore TR (2010) Linking root production to aboveground plant characteristics and water table in a temperate bog. Plant Soil 336:219-231

Nykänen H, Alm J, Silvola J, Tolonen K, Martikainen PJ (1998) Methane fluxes on boreal peatlands of different fertility and the effect of long-term experimental lowering of the water table on flux rates. Global Biogeochem Cycles 12:53-69
Pavelka M, Acosta M, Marek MV, Kutsch W, Janous D (2007) Dependence of Q10 values on the depth of the soil temperature measuring point. Plant Soil 292:171179

Pfadenhauer J (1997) Vegetationsökologie. Eching, pp 448

PN-G-04595 (1997) Peat and peat production. Determination of degree of decomposition. ISBN-83-236-0925-X, pp 9

PN-G-04596 (1997) Peat and peat production. Determination of degree of ash content. ISBN-83-236-0641-2, pp 2

Raich JW, Schlesinger WH (1992) The global carbon dioxide flux in soil respiration and its relationship to vegetation and climate. Tellus 44B:81-99

Reichstein M, Rey A, Freibauer A, Tenhunen J, Valentini R, Banza J, Casals P, Cheng YF, Grunzweig JM, Irvine J, Joffre R, Law BE, Loustau D, Miglietta F, Oechel W, Ourcival JM, Pereira JS, Peressotti A, Ponti F, Qi Y, Rambal S, Rayment M, Romanya J, Rossi F, Tedeschi V, Tirone G, Xu M, Yakir D (2003) Modeling temporal and largescale spatial variability of soil respiration from soil water availability, temperature and vegetation productivity indices. Global Biogeochem Cycles 17:1-15

Riutta T, Laine J, Tuittila E-S (2007) Sensitivity of $\mathrm{CO}_{2}$ exchange of fen ecosystem components to water level variation. Ecosystems 10:718-733

Robroek BJM, Limpens J, Breeuwer A, Schouten MGC (2007) Effects of water level and temperature on performance of four Sphagnum mosses. Plant Ecol 190:97107

Robroek BJM, Schouten MGC, Limpens J, Berendse F, Poorter $H$ (2009) Interactive effects of water table and precipitation on net $\mathrm{CO} 2$ assimilation of three co-occurring Sphagnum mosses differing in distribution above the water table. Glob Chang Biol 15(3):680-691

Silvola J, Alm J, Ahlholm U, Nykänen H, Martikainen PJ (1996) $\mathrm{CO}_{2}$ fluxes from peat in boreal mires under varying temperature and moisture conditions. J Ecol 84:219-228

Suleau M, Moureaux C, Dufranne D, Buysse P, Bodson B, Destin J-P, Heinesch B, Debacq A, Aubinet M (2011) Respiration of three Belgian crops: partitioning of total ecosystem respiration in its heterotrophic, above- and below-ground autotrophic components. Agric For Meteorol 151:633-643

Sulman BN, Desai AR, Cook BD, Saliendra N, Mackay DS (2009) Contrasting carbon dioxide fluxes between a drying shrub wetland in Northern Wisconsin, USA, and nearby forests. Biogeosciences 6:1115-1126

Tuittila ES, Vasander H, Laine J (2004) Sensitivity of C sequestration in reintroduced Sphagnum to water-level variation in a cutaway peatland. Restor Ecol 12:483-493Updegraff K, Pastor J, Bridgham SD, Johnston CA (1995) Environmental and substrate controls over carbon and nitrogen mineralization in northern wetlands. Ecol Appl 5:151-163

Updegraff K, Scott DB, Pastor J, Weishampel P (1998) Hysteresis in the temperature response of carbon dioxide and methane production in peat soil. Biogeochemistry 43:253-272Updegraff K, Bridgham SD, Pastor J, Weishampel P, Harth C (2001) Response of $\mathrm{CO}_{2}$ and $\mathrm{CH}_{4}$ emissions in peatlands to warming and water table manipulation. Ecol Appl 11:311-326 
Waddington JM, Rotenberg PA, Warren FJ (2001) Peat $\mathrm{CO}_{2}$ production in a natural and cutover peatland: implications for restoration. Biogeochemistry 54:115130

Ward SE, Ostle NJ, McNamara NP, Bardgett RD (2010) Litter evenness influences short-term peatland decomposition processes. Oecologia 164:511-520
Weltzin JF, Bridgham SD, Pastor J, Chen JQ, Harth C (2003) Potential effects of warming and drying on peatland plant community composition. Glob Chang Biol 9:141-151

Wojterska M (2001) The vegetation of Wielkopolska and Southern Pomerania lakeland regions: field session guide, 52. Polish Botanical Society Meeting, 24-28 September 2001, (in Polish) 